\title{
Plastic Materials and Chemical Substances Used for Kidney's Anatomic Study
}

\begin{abstract}
SORIN LUCIAN BOLINTINEANU, ALINA MARIA SISU*, AGNETA MARIA PUSZTAI, ELENA POP
Victor Babes University of Medicine and Pharmacy, Department of Anatomy and Embryology, 2 Eftimie Murgu Sq., 300041, Timisoara, Romania

Over time, anatomists have been concerned with the preservation of anatomical parts for a long time. Thus, in the modern era, both colouring and fixing substances, as well as plastic and corrosive materials have been used in the manufacture of corrosion and plastinated specimens. The ultimate aim was to make the dissected anatomical specimens as lasting and accurate as possible. Thus, parenchymal viscera, which have a certain tissue thickness, greater than in the tubular viscera, are more difficult to preserve and obviously to dissect. The time required to preserve those increases accordingly. In our study we have used 62 formalized adult human kidneys, belonging to 31 bilateral dissected bodies, different age and gender, 20 males and 11 females. We have removed all the kidneys from the renal fossa and we have made 23 corrosion casts, and 39 specimens have been plastinated. There have been dissected 30 structures considered as normal in size and morphological aspect and 9 have been preserved entirely because they did not fit within the normal physiological limits. All 39 kidneys have been undergone to S10 Biodur rubber silicone technique preservation.
\end{abstract}

Keywords: corrosion, plastination, kidney, S10 Biodur

The most efficient techniques over the years include corrosion and plastination techniques. Starting with the 19th century, injection of plastic materials and fixing substances into the blood vessel system led to a better understanding of anatomical structures, both in vivo and after their accurate dissection [1-3]. The highest efficiency and best accuracy have been proven by plastination techniques, by undergoing the anatomical structures to a complex polymerization and silicone processes. These have allowed the dissected parts to look as good as possible for a long time without any risk of decaying in time or toxicity.

\section{Experimental part}

We have dissected 62 formalized adult human kidneys, from 31 bilateral bodies of different age and gender, 20 males and 11 females, belonging to Anatomy and Embryology Laboratory, Department of Anatomy and Embryology, Victor Babes University of Medicine and Pharmacy from Timisoara.

We have made an in situ study for all the specimens, in order to see the external morphological aspect and the relationship between the kidneys and the surrounding viscera. We have removed all the kidneys from the renal fossa and we have made 23 corrosion casts, and 39 kidneys have been plastinated. There have been dissected 30 structures considered as normal in size and morphological aspect and 9 have been preserved entirely because they did not fit within the normal physiological limits. All 39 kidneys underwent the S10 Biodur rubber silicone technique preservation.

The plastination process comprises four phases: fixation, dehydration, forced impregnation and final treatment (hardening). In our laboratory we have formalized the specimens to be plastinated, using a $10 \%$ formaldehyde solution. For the fixation it has been used $200 \mathrm{~mL}+15 \mathrm{~g}$ of potassium nitrate $+30 \mathrm{~g}$ of potassium acetate. The fixation was carried out in a mixture of acetone
(95 parts) and formaldehyde ( 5 parts) at $-25^{\circ} \mathrm{C}$, for a period of 24 days.

As a dehydration agent we have used a mixed acetone and ethanol. The standard dehydration period is 4-5 weeks. We have prolonged the period to 6 weeks, precisely because of kidney plastination, which are parenchymatous structures, full of water and fat. We have used only renal sections during this standard period. We considered, like other authors, that dehydration was complete when the water in the last acetone bath was below $1 \%$. We have used as additional degreasing agent methylene chloride. In particular, full renal specimens required a longer dehydration time, even up to 8 weeks, to ensure total water removal [4].

Forced impregnation required increased attention, being the most important step in plastination. Using S10Biodur rubber silicone, it was mandatory to make it at $-25^{\circ} \mathrm{C}$ in a vacuum chamber under reduced pressure. Having an increased density of the specimens, the time required for impregnation was also increased (3-4 weeks) [5].

Hardening is a process by which the polymer molecules unite and harden the specimen (due to the use of the S3 Biodur curing polymer). Treatment with $\mathrm{S6}$ Biodur as steam is the final phase of the process, which, in order to be durable, takes several months. Kidneys, as well as parenchymal structure and density, require about 230-210 days of finishing process. We have finished the specimens between 240-298 days [6,7].

The kidneys undergoing the corrosion process have been studied in terms of intraparenchymatous variation, regarding the variability of the renal pedicle, which is even more difficult to achieve even by plastination. The renal vasculo-ductal system has been injected with plastic materials (E950-AGO nitrocellulose, paste II), based on the method used by Nanu, Corondan and Bejan. Then, the renal parenchyma has been subjected to corrosion with hydrochloric acid. After completion of all stages, renal corrosion specimens have been individually photographed

* email: alinasisu@gmail.com; alinasisu@umft.ro; Phone: +40724361671 
and sorted according to the morphological type of the renal artery [8-10].

\section{Results and discussions}

We have preserved 9 full kidneys, 30 plastinated sliced kidneys and 23 corrosion specimens after plastic injection and subsequent corrosion.

Our studies have focused on the knowledge and evidence of macroscopic and mesoscopic renal structures, renal segments, renal pyramids, renal vasculature, and normal anatomical variants. Also, kidney's pathology is susceptible of being highlighted by plastination techniques. Corrosion techniques have shown, in our case, the existence of normal anatomical variants of variable morphology. The size, shape, colour, and macroscopic appearance of the kidneys have been highlighted by plastination techniques using the S10 Biodur silicone technique.

The three-dimensional distribution of renal anatomical structures is evidenced by the use of modern imaging techniques, but also by macroscopic and mesoscopic dissection, corrosion and plastinated specimens. Corrosion specimens have showed the spatial distribution of kidney pedicle elements as well as their branches and their relationship to renal parenchyma.

In a study published in 2017, Pop et all. [11] 150 kidney underwent corrosion tecnique, in order to examine the posterior segmentary renal artery and renal morphological variability. The following morphological types were identified: Type I, with bifurcation in an anterior and posterior branch (in $92.67 \%$ of cases), type II, trifurcate in anterior, posterior and upper or lower branches (in 6.00\% of cases ) type III, quadrifurcation in an anterior branch, posterior, superior and inferior (in $1.33 \%$ of cases). And in our study, we have met the typology I in 16specimens, the II typology in 7 specimens and the typology III in no specimen. As percentages we are close to the limits found in specialized literature: betw een 27.00 and $63.20 \%$ of the cases. In literature, the morphological type I varies between 38.77 and $56.32 \%$. Typology $\mathrm{III}$, although found in literature (2\%), in our study no specimen have showed this variant.

Data correlation from anatomical studies with certain specific kidney pathologies[12], but also with the embryological aspects that can lead to normal morphological variants, implies a very good knowledge of the renal vascular distribution, both of surgeons and of nephrologists, and last but not least of students and residents interested in renal pathology, including coeliac and aortico-renal lymph nodes [13]. Modern methods for identifying the morphological variants of the segmental branches of the renal artery are plastination and corrosion. These methods allow us to clearly highligh the threedimensional distribution of the renal artery and its branches, as well as their relationship with the neighboring structures of the renal pelvis, renal vein, renal pelvis, large and small calyces lymph, nerves [14].

While plasticination allows cross-sectional structures to be highlighted in a specimen, including renal parenchyma, corrosion shows the spatial vascular distribution of the studied renal elements [15-17].

Renal pedicle is a variable structural complex, which can undergo both dissection, and plastination and corrosion. The renal calyceal system and possible kidney malformations can also be highlighted by these methods. These substances have been successfully used in the preservation of other parts of the body, such as the dentoalveolar system or the femur bone, the concentration and possible interactions with other substances being very important [18-26].

Renal parenchymal resections can be performed with minimal risk when the surgeon knows in detail the kidney structures and the elements in relation to them. From morphopathological point of view, it is useful to know the distribution of these structures and in rare cases of supernumerary kidneys or unilateral renal agenesis, both plastination and corrosion methods are accurate for studying of the specimens.

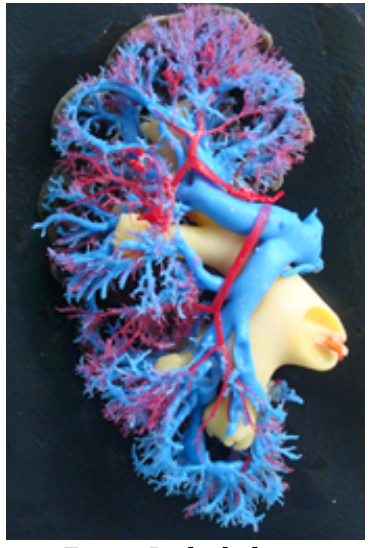

Fig. 1. Right kidney

(corrosion cast),

highlighting the venous and arterial structures, as well as renal pelvis

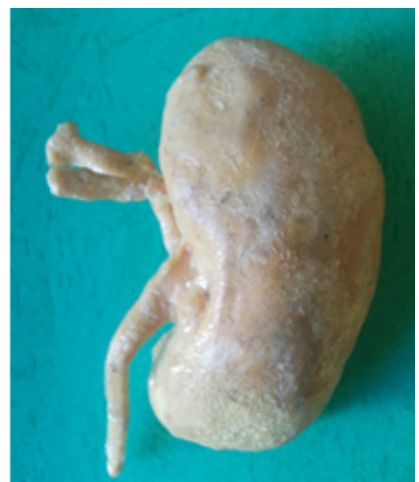

Fig. 3. Plastinated left kidney (renal capsule, ureter, renal artery). S10 Biodur technique

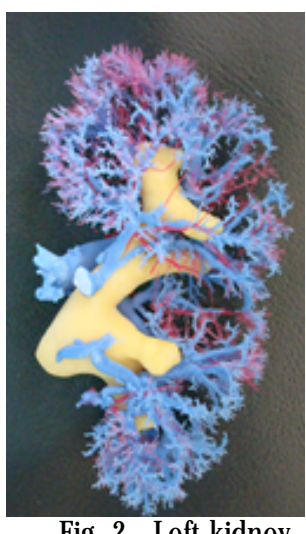

Fig. 2. Left kidney (corrosion cast), highlighting the arterial branches and venous tributaries

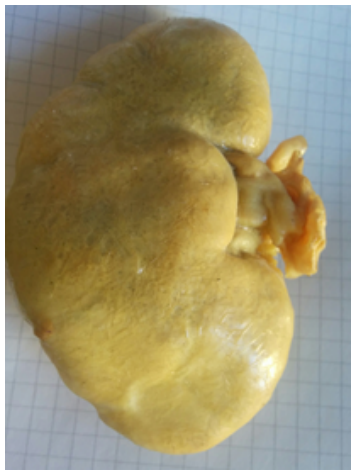

Fig. 4. Plastinated right kidney (renal lobules, renal pelvis, renal vessels). S10

Biodur technique

\section{Conclusions}

We have noticed that acetone is an ideal desiccant solvent and is also a good degreasing agent for the kidneys, since containing a large amount of fat. However, due to the high cost it is advisable to use a mixture of acetone and ethanol.

Plastination allows for anatomical specimens a high resistance to maneuvering as well as no toxicity.

The use of plastination also allows the study of external and internal feature of specimens, both for medical (research) and educational purposes.

Plastic materials injection and corrosion afford the spatial study of renal vessels but also the identification of different renal morphological types.

Both plastination and plastic materials injection enable the study of the normal and pathological kidney.

Aknoledgement: Present study was supported by funds kindly provided by Victor Babes University of Medicine and Pharmacy Timisoara, Romania, through P-III-C5-PCFI-2017/2018-03 Internal grant acronym UROVESSELS. 


\section{References}

1.VON HAGENS, G. - Curing with the S10 Standard Technique, Technical leaflet. Anatomisches Institut 1, Universtat Heidelberg, 1984.

2.MAHAJ AN, A, AGARWAL, S, TIWARI, S, VASUDEVA, N. Plastination: An Innovative Method of Preservation of Dead Body for Teaching and Learning Anatomy. MAMC J Med Sci ,NO. 2, 2016, p .38-42.

3.RIEDERER, B,M. Plastination and Its Importance in Teaching Anatomy. Critical Points for Long-term Preservation of Human Tissue, J Anat, 224, 2014, p.309-315.

4.BOLINTINEANU, S.L., POP, E., STANCU, G., STANCU,G., VAIDA, M.A., SISU, A.M., PATRASCU, J.M., FLORESCU,S., Anatomical Structures Preservation Using Plastination Techniques, Mat. Plast., 54, no.2, 2017, p.221-224.

5.OTTONE, N,E, CIRIGLIANO, V, BIANCHI, H,F, MEDAN, C,D, ALGIERI,R,D, BORGES, BRUM, G, FUENTES, R, New Contributions to the Development of a Plastination Technique at Room Temperature with Silicone, Anat Sci Int. Mar; 90, N0.2, 2015,p.126-135.

6.WEBER, W, WEIGLEIN, A, LATOORRE, R, HENRY, R,W. Polyster Plastination of Biological Tissue- P35 Technique,J Int Soc Plastination, 20, 2007, p.50-58.

7.BOLINTINEANU,S.L., PUSCASIU,D.A., PETRESCU, C.I., etal., Injected and Colouring Substances Largely Used in Processing Microscopic Anatomical Structures, Mat. Plast., 54, no. 3, 2017, p.505-509.

8.SISU, A.M., NODITI, G., GRIGORESCU, D., et al., The Benefits of the Plastination Techniques for the Anatomo Clinical Studies of Ankle J oint Ligaments Injuries, Mat. Plast., 54, no. 3, 2017, p. 487-490.

9.PASHAEI, S. A Brief Review on the History, Methods and Applications of Plastination, Int J Morphol, 28, 2010, p.1075-1079.

10.SORA, M.C, ERMAN, G, PIRTEA, L, BOIA, M, MATUSZ, P, SAS, I. Mat.Plast., 52, no.3, 2015, p.381.

11.POP, E., SARAU, C.A., BARDAN,R., LIGHEZAN, D.F., LATCU, S., SAPTE, E.,PUSZTAI, A.M., SAVOIU BALINT,G., BOLINTINEANU, S.L., Morphological Variations of Posterior Segmental Artery of the Single Renal Artery, Study on corrosion casts, Mat. Plast., 54, no.2 , 2017, p. 338-340.

12.TATU RF, ANUSCA DN, GROZA S, MARUSCIAC L, BOJ IN FM, TATU C, HURMUZ M, PAUNESCU V, Morphological and functional characterization of femoral head drilling-derived mesenchymal stem cells, Romanian Journal of Morphology and Embryology, 2014, 55(4), p.1415-1422

13.SISU, ALINA MARIA; PETRESCU, CODRUTA ILEANA; CEBZAN, C. C.; et al., The adult coeliac ganglion: a morphologic study, ROMANIAN JOURNAL OF MORPHOLOGY AND EMBRYOLOGY, 49, 4, 2008, p.491494.
14.PENTEA, M, HULEA ,C, STANCU, A., BUTNARIU, M, CRISTINA, R,C., Developing the plastination laboratory for the technique S10, Mat. Plast. 53, no.1, 2016, p.150

15.SORA, MC, MATUSZ, P., Clin. Anat., 23, no.6, 2010, p.734.

16. SORA, M.C, FEIL, P., BINDER, M, MATUSZ, P., PLES, H., Mat. Plast.,52, no.1, 2015, p.75.

17. SORA, M.C, BINDER, M., MATUSZ, P., PLES, H., SAS, L, Mat. Plast.,52, no.2, 2015, p.186.

18.SZUHANEK, C. PARASCHIVESCU, E. GADEA; SISU, ALINA MARIA; et al., Cephalometric investigation of Class III dentoalveolar malocclusion, ROMANIAN JOURNAL OF MORPHOLOGY AND EMBRYOLOGY, 52, 4, 2011, p.1343-1346.

19.HENRY, R,W, Polyester Plastination Techniques, Specific Troubles and Problems. Murcia, Spain, 12th International Conference on Plastination, 2004, p.23-24.

20.CAPLESCU, C., MARSAVINA, L., BORDEASU, I., SECHEI, R., M., The Fracture of Polyurethane Materials in the Presence of Stress Concentrators, Mat. Plast.,47, no.3, 2010, p. 379

21.SISU, ALINA MARIA; TATU, F. R.; STANA, LOREDANA GABRIELA; et al., Chondrosarcoma of the upper end of the femur, ROMANIAN JOURNAL OF MORPHOLOGY AND EMBRYOLOGY, 52, 2 ,2011, p.709713.

22.GHIBAN, N., BORTUN!, M., BORDEASU, I., GHIBAN, B., FAUR,N., CERNESCU, A., Evaluation of mechanical properties by stereo-and scanning electron microscopy of some heat curing dental resins, Mat. Plast.,47, no.2, 2010, p. 240-243

23.AHMADI, M., PUP, M., OLARIU, L., VERMESAN, H., PREJ BEANU, R.; Manganese and zinc overdose-risk of oxidative stress appearance, Rev. Chim. (Bucharest), 59, no. 9, 2008, p. 982-985.

24.PREJ BEANU, R., AHMADI, M., SCURTU, M, VERMESAN, D., OLARIU, $\mathrm{L}$., Influence of zinc and manganese overdoses in biosystems, Rev. Chim. (Bucharest), 62, no. 7, 2011, p. 750-752.

25.DELEANU, B., SCURTU, M „, AHMADI, M., TULCAN, C,. PREJ BEANU, R., DRONCA, D., Mineral micronutrients in rabbits' radius after aluminum administration, Rev. Chim. (Bucharest), 66, no. 9, 2015, p. 1306-1308.

26.AHMADI, M., DELEANU, B., OSTAN, M., STANCU, A., DRONCA, D.; SCURTU, M., CREESCU, I., In vivo experiments on zinc toxicity, Rev. Chim. (Bucharest), 67, no. 10, 2016, p. 2015-2017.

27.PUSCASIU D, TATU C, TATU RF, POTENCZE, POPESCU R, MUNTEAN I, VERDES D, The significance of angiogenesis and tumoral proliferation in renal cell carcinoma, Rom J Morphol Embryol, 2011, 52, 1Suppl, p. 369-372.

Manuscript received: 27.05 .2018 